\title{
Nowoczesne obrazowanie z wykorzystaniem techniki wydruku 3D - technologia wspomagająca leczenie złożonych wrodzonych wad serca u dzieci
}

\section{Modern visualization using 3D printing technique - supporting technology in treating of complex congenital heart diseases in children}

\author{
Radosław Jaworski ${ }^{1}$, Ireneusz Haponiuk ${ }^{1,2}$, Maciej Chojnicki ${ }^{1}$, Mariusz Steffens ${ }^{1}$, \\ Henryk Olszewski ${ }^{3}$, Konrad Paczkowski ${ }^{1}$, Ninela Irga-Jaworska ${ }^{4}$, Katarzyna Gierat-Haponiuk ${ }^{2,5}$ \\ ${ }^{1}$ Oddział Kardiochirurgii Dziecięcej Szpitala im. św. Wojciecha, Copernicus PL Sp. z o.o. w Gdańsku \\ ${ }^{2}$ Katedra Fizjoterapii Wydziału Rehabilitacji i Kinezjologii Akademii Wychowania Fizycznego i Sportu im. Jędrzeja Śniadeckiego w Gdańsku \\ ${ }^{3}$ Instytut Informatyki Stosowanej im. Krzysztofa Brzeskiego Państwowej Wyższej Szkoły Zawodowej w Elblągu \\ ${ }^{4}$ Katedra i Klinika Pediatrii, Onkologii i Hematologii Gdańskiego Uniwersytetu Medycznego \\ ${ }^{5}$ Klinika Rehabilitacji Gdańskiego Uniwersytetu Medycznego
}

\section{Streszczenie}

Techniki wydruku 3D coraz częściej wykorzystuje się we współczesnej medycynie. Podsumowano aktualny stan wiedzy dotyczący tej technologii i możliwości jej zastosowania w leczeniu złożonych wrodzonych wad serca u dzieci.

Słowa kluczowe: wydruki 3D, biowydruki, wrodzone wady serca, kardiochirurgia dziecięca

Folia Cardiologica 2016; 11, 5: 409-414

\section{Wstęp}

Obrazowanie przestrzenne z wykorzystaniem wydruków trójwymiarowych (3D, 3-dimensional) stosuje się w wielu dziedzinach życia. Główne zastosowanie tej technologii dotyczy projektowania i wdrażania różnorodnych części i prototypów w przemyśle. Coraz częściej techniki wydruku 3D wykorzystuje się we współczesnej medycynie [1]. Zastosowanie tej technologii w różnych gałęziach nauk biologiczno-medycznych może przynieść liczne korzyści w badaniach podstawowych, rozwoju technologii diagnostycznych i terapeutycznych oraz w medycynie klinicznej. Nowe możliwości i oczekiwania klinicystów są związane głównie z tworzeniem przestrzennego wydruku rozszerzającego dotychczas dostępne obrazowanie jednopłaszczyznowe. W bezpośrednim ujęciu klinicznym szczególnego znaczenia nabiera uzyskanie dokładnego, spersonalizowanego i dostosowanego do indywidualnych potrzeb pacjenta obrazu o wyglądzie modelu wybranego obszaru ciała, narządu czy tkanki [2]. Poza produkcją leków, w której potwierdzono przydatność tej technologii, medyczne zastosowanie wydruków 3D znajduje praktyczną - kliniczną przestrzeń w takich dziedzinach, jak ortopedia, kardiochirurgia, neurochirurgia, onkologia i hematologia, chirurgia onkologiczna, chirurgia szczękowa i urologia. Ostatnio ukazały się publikacje dotyczące wydruków 3D kości, uszu, części szkieletu, tchawicy, naczyń krwionośnych oraz tkanek miękkich [2]. Prowadzone są także prace dotyczące wykorzystania tych technik w produkcji leków oraz w sposobach ich dystrybucji.

W doświadczeniu autorów niniejszego opracowania do wydruku 3D modelu serca wykorzystano standardowo dostępne badania radiologiczne. Do modelowania tkanek miękkich - serca i płuc - wykorzystano monochromatyczne

Adres do korespondencji: dr n. med. Radosław Jaworski, Oddział Kardiochirurgii Dziecięcej, Szpital im. św. Wojciecha, Copernicus PL Sp. z 0.o., aleja Jana Pawła II 50, 80-462 Gdańsk, e-mail: radicis@go2.pl 


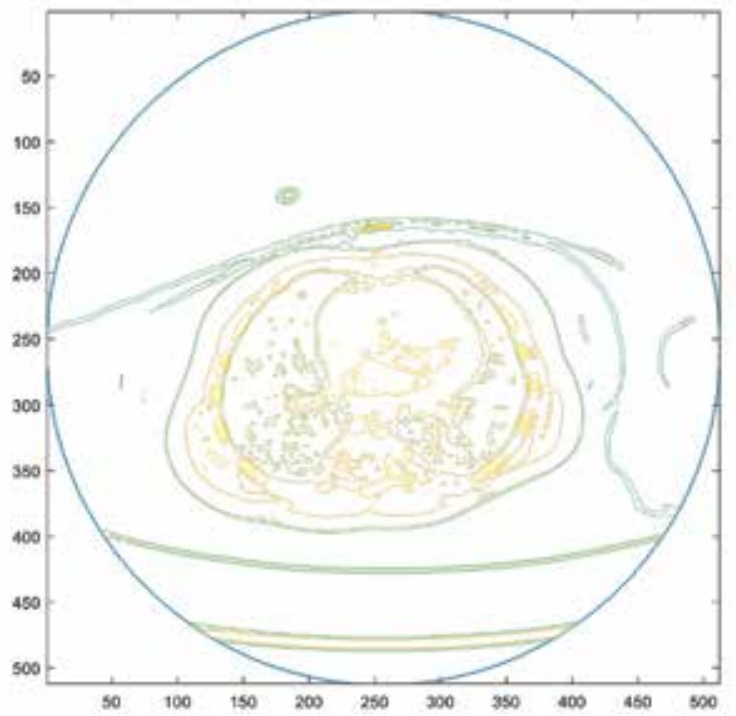

Rycina 1. Model warstwicowy 2D wyróżnionych tkanek

obrazy przekrojów ciała ludzkiego zapisane w standardzie DICOM. Każdy obraz DICOM jest macierzą, która zawiera opis poziomów szarości punktów obrazu. Powyższe poziomy szarości skojarzono z poszukiwanymi tkankami (ryc. 1). W celu wyodrębnienia z obrazu punktów odpowiadających danej tkance poszukiwano zbiory punktów, których poziomy szarości mieszczą się w zadanym przedziale przyporządkowanym danej tkance. $W$ rezultacie wygenerowano w poszczególnych obrazach przekrojowych zbiory krzywych modelu warstwicowego (ryc. 2). W kolejnym etapie obliczeń na bazie modelu warstwicowego utworzono model siatkowy składający się z dwuwymiarowych simpleksów - trójkątów. Generowanie modelu siatkowego wymagało wykonania kilku operacji: wygładzania krzywych, usuwania nieciągłości modelu geometrycznego, rozpinania dodatkowych simpleksów. Otrzymany model siatkowy po wypełnieniu czworościanami (trójwymiarowymi simpleksami) zapisano w formacie stereolitograficznym (STL, stereolithography) i wydrukowano na drukarce 3D.

Możliwości zastosowania technik wydruków 3D obejmują wiele aspektów klinicznych. W wielu dziedzinach zabiegowych, w tym także w kardiochirurgii, modelowanie struktur anatomicznych, zmienionych patologicznie w procesie choroby organów, planowanie chirurgiczne oraz produkcja indywidualnie dobranych do potrzeb pacjenta elementów wszczepialnych (śruby, płytki, uzupełnienia tkanek itp.) zyskuje popularność. Możliwe jest dokładne planowanie operacji z wykorzystaniem rzeczywistego obrazu anatomicznego operowanego narządu. Ponadto technika ta umożliwia operatorowi „przećwiczenie” wybranej strategii, w tym ewentualnych opcji alternatywnych, przed rozpoczęciem rzeczywistej procedury chirurgicznej u pacjenta długo przed wejściem na salę operacyjną.

Efektem modelowania przestrzennego, najbardziej oczekiwanym przez profesjonalistów, będzie poprawa bezpieczeństwa procedur, szczególnie trudnych technicznie i niestandardowych zabiegów operacyjnych, z osiągnięciem doskonalszych wyników leczenia [3]. Podejmuje się również próby wydruku gotowych elementów, które docelowo można implantować konkretnemu pacjentowi. Największe, jak dotychczas, doświadczenia zdobyto w zakresie uzupełniania ubytków kostnych w różnych lokalizacjach z wykorzystaniem

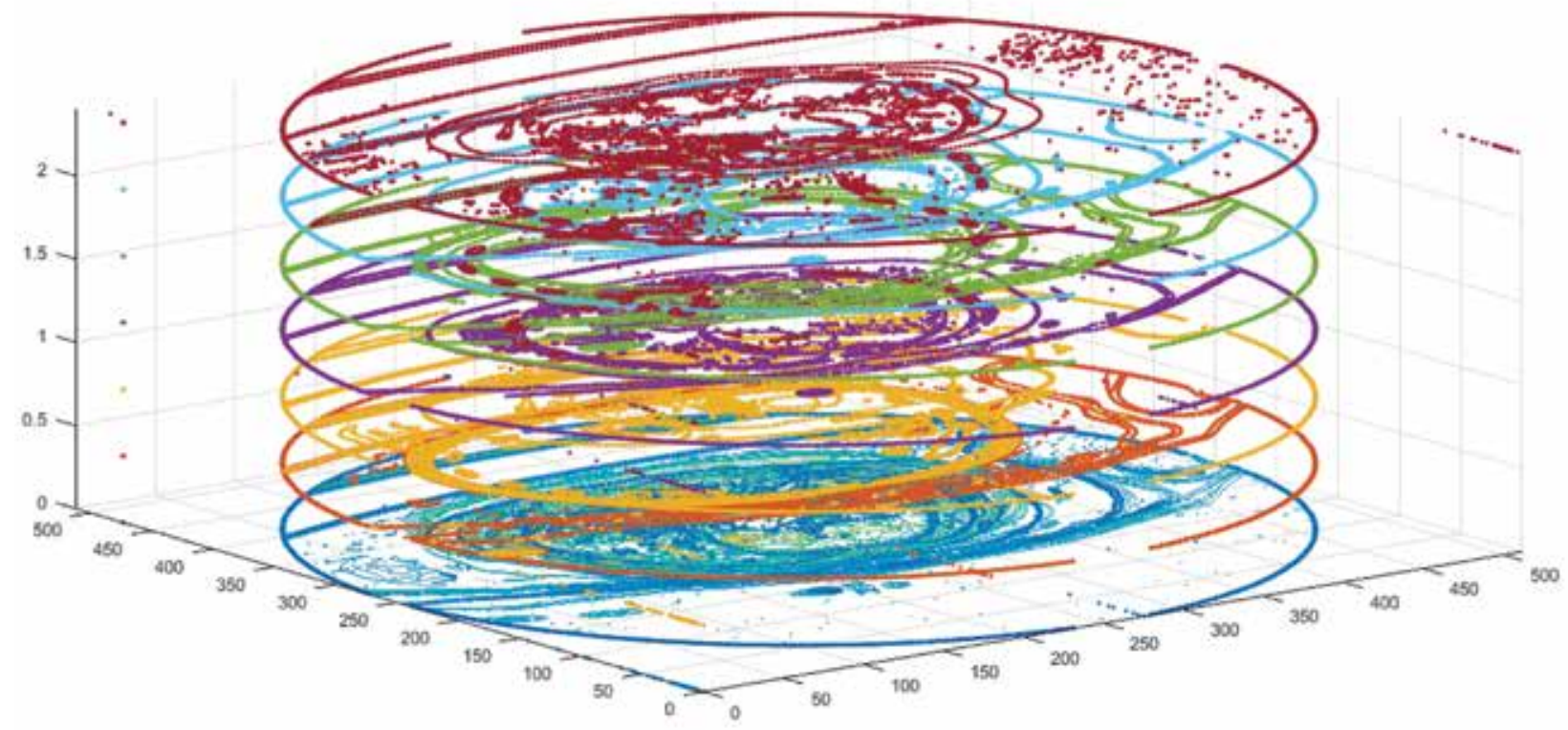

Rycina 2. Zbiory krzywych trójwymiarowego modelu warstwicowego 
wydrukowanych w technologii 3D gotowych „wszczepów” ze stopów tytanu [4]. Prowadzone są także próby kliniczne implantowania elementów kostnych wydrukowanych techniką 3D u dzieci. Przykładem wykorzystania implantowalnych wydruków 3D jest zastosowanie wydrukowanych szyn podtrzymujących drożność oskrzeli w przypadkach tracheobronchomalacji u dzieci, powstałych w następstwie mechanicznego uszkodzenia chrzęstnych elementów głównych dróg oddechowych [5].

W kardiochirurgii wydruki są stosowane głównie w planowaniu operacji u chorych, u których przewiduje się występowanie złożonych warunków anatomicznych [6]. Dodatkowe techniki tak zwanych interaktywnych wydruków 3D umożliwiają symulację efektu terapeutycznego. Podejmowane są również próby opracowania technologii wydruków 3D umożliwiającej stworzenie wszczepialnych komponentów zastawek serca [7].

Wydruki 3D są przydatne w przedoperacyjnej wizualizacji wrodzonych wad serca u dzieci, pomagają w planowaniu zabiegów oraz w symulacji przedoperacyjnej u konkretnego pacjenta na podstawie dokładnego odwzorowania szczegółów anatomicznych. Należy tu wspomnieć o oczekiwanym rozwoju technologii biowydruków, które w najbliższym czasie mogą dostarczyć alternatywnych protez i gotowych implantów, a tym samym zrewolucjonizować leczenie wybranych wrodzonych wad serca u dzieci [8]. Technologia biowydruków 3D jest obecnie ukierunkowana na stworzenie wszczepialnej zastawki aortalnej [9]. Podejmuje się intensywne próby wydrukowania w 3D struktur zastawkowych z wykorzystaniem hydrożeli $[8,10,11]$. W cytowanych badaniach uzyskano wysoką przeżywalność struktur biologicznych, takich jak hodowle tkankowe, jako materiałów stosowanych w wydrukach 3D (> 90\%), jednak ich właściwości mechaniczne (elastyczność i wytrzymałość) pozostają jeszcze dalekie od oczekiwań. W kardiochirurgii dziecięcej brakuje obecnie materiałów, które po wszczepieniu do organizmu dziecka wykazałyby pełną biozgodność i zdolność rozwoju wraz ze wzrostem dziecka. Jest to istotne zwłaszcza w wadach zastawkowych, których korekcja wymaga uzupełnienia płatków zastawek z wykorzystaniem obcych, biologicznych materiałów lub ich całkowitej wymiany. Podobne problemy braku wzrostu implantu determinuja odległe wyniki rozległych operacji naprawczych, wymagających wszczepiania protez u bardzo małych dzieci. Brak wzrostu implantowanego materiału, niejednokrotnie mimo zachowania jego struktury i właściwości biologicznych, wymaga wykonania powtórnej, możliwej do przewidzenia w czasie, operacji u dorastającego pacjenta z wrodzona wadą serca. Zjawisko to zyskało swoją nazwę w prognozowaniu odległych efektów w kardiochirurgii dziecięcej - jest określane mianem „przerastania” serca powyżej rozmiarów definiowanych dla wszczepionego implantu (graft overgrowth).
Analizując korzyści, które można osiągnąć dzięki technologii wydruków 3D u dzieci z wrodzonymi wadami serca i dużych naczyń, należy zwrócić uwagę na możliwe obecnie obszary ich wykorzystania.

\section{Planowanie operacji kardiochirurgicznych}

Wydrukowane modele 3D w kardiochirurgii dziecięcej umożliwiają dokładne odwzorowanie struktur w zakresie anatomii, a także odwzorowanie naturalnych warunków w skali 1:1. Technologia przygotowania modeli 3D do wydruku umożliwia przedstawienie szczegółów budowy i relacji anatomicznych żywego organizmu zarówno w zakresie kośćca, unaczynienia, jak i tkanek miękkich. Zastosowanie rozpuszczalnych w roztworach zasadowych materiałów podporowych (tzw. supportu), utwierdzających po wydruku materiał budulcowy, umożliwia - po wydrukowaniu modelu - dokładną wizualizację skomplikowanych elementów strukturalnych i ich zależności w stosunku do innych organów. Wydruk sieci naczyń płucnych pozwala na planowanie interwencji nie tylko w torakochirurgii, ale również w kardiochirurgii dziecięcej [12]. W ośrodku autorów tego opracowania pierwszy wydruk 3D serca i dużych naczyń u dziecka dotyczył 6-miesięcznego chłopca z atrezją płucną i ubytkiem w przegrodzie międzykomorowej (ryc. 3) [13]. Dokładne odwzorowanie skomplikowanych wad anatomicznych umożliwiło dalsze planowanie kolejnych zabiegów kardiochirurgicznych u tego pacjenta. Wydaje się również, że precyzyjna wizualizacja poszczególnych struktur narządowych na wydrukowanym modelu 3D i odzwierciedlenie

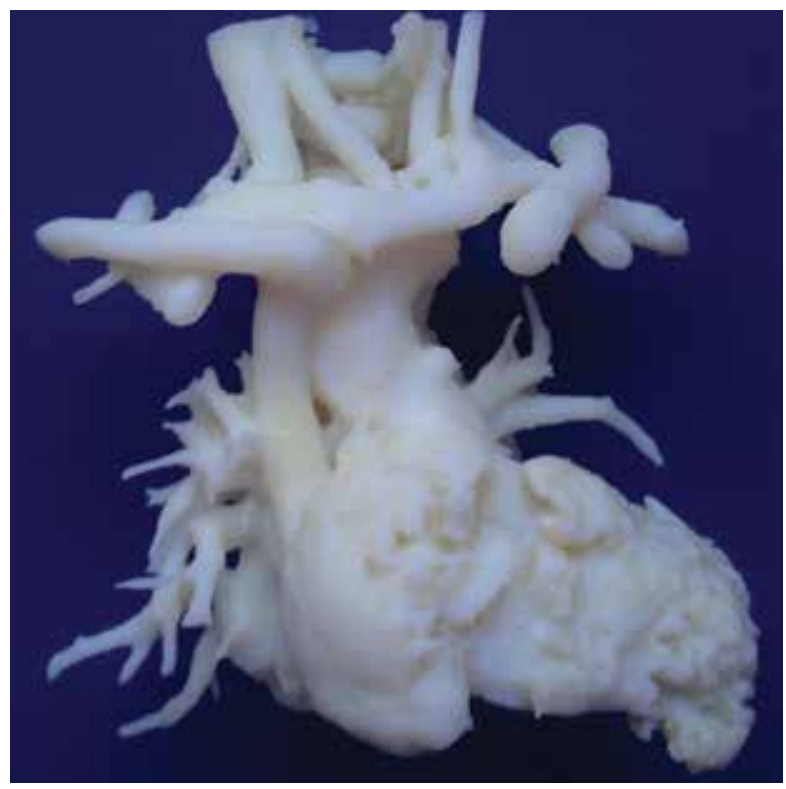

Rycina 3. Wydruk 3D serca i dużych naczyń u 6-miesięcznego chłopca z atrezją płucną i ubytkiem w przegrodzie międzykomorowej 
dokładnych przestrzeni między nimi umożliwi w niedalekiej przyszłości projektowanie odpowiednich narzędzi chirurgicznych oraz sposobów ich właściwego umieszczenia w polu operacyjnym pacjenta podczas operacji [14].

\section{Symulacja technik operacyjnych}

Wydruki 3D serca wykonane z odpowiednich materiałów mogą umożliwić przeprowadzenie symulacji planowanego zabiegu na wydrukowanym modelu. Nie sposób nie docenić hipotetycznych korzyści wynikających z możliwości próbnego wykonania plastyki zastawki przedsionkowo-komorowej u dziecka ze wspólnym kanałem przedsionkowo-komorowym czy też przygotowania drogi wypływu z prawej komory serca u pacjentów z tetralogią Fallota. Również dobór odpowiednich wymiarów i dopasowania łaty do zamknięcia na przykład ubytku w przegrodzie międzykomorowej można sprawdzić na wydruku 3D. Należy jednak podkreślić, że ograniczeniem metody jest statyczność modelu 3D oraz brak możliwości sprawdzenia funkcji serca po interwencji oraz ich zmian hemodynamicznych po zabiegu. Wydrukowane modele 3D nie uwzględniają patofizjologii ani mechaniki płynów, tak ważnych w kardiochirurgii [15]. Przykładem mogą być pacjenci z kardiomiopatią przerostową, w przypadku której na podstawie badań tomografii komputerowej (CT, computed tomography) tworzony jest model serca 3D z materiału podlegającego „treningowej” obróbce chirurgicznej (np. hydrożel). Następnie na tak przygotowanym modelu 3D wykonuje się wycięcie przerośniętej mięśniówki przegrody międzykomorowej - miektomię i uzupełnia pomiary wolumetryczne [16]. W kardiochirurgii dorosłych Schmauss i wsp. [17] opisali zastosowanie technik wydruku 3D u pacjentów z wadami łuku aorty. Zastosowanie do wydruku odpowiednich materiałów podobnych do gumy umożliwiło pełną symulację zabiegu korekcji wady z zastosowaniem szwów. Należy zatem oczekiwać rozwoju dodatkowej technologii badawczej umożliwiającej symulację dynamiki i analize przepływów w modelach pozyskanych dzięki technice wydruku 3D.

Z praktycznego, istotnego dla chirurga, punktu widzenia ważnym argumentem za zastosowaniem technologii wydruków 3D może być również przyspieszenie rzeczywistej procedury kardiochirurgicznej dzięki wykorzystaniu przygotowanych wcześniej, „uszytych na miarę” elementów implantowalnych. Stanowi to przewage nad obecnie dostępnymi uniwersalnymi lub koniecznymi do przygotowania materiałami biologicznymi, których przygotowanie do bezpośredniej implantacji odbywa się na sali operacyjnej, w trakcie zabiegu, co często wydłuża procedurę chirurgiczną i nie jest korzystne dla chorego.

Problemem współczesnej medycyny rekonstrukcyjnej, w tym także kardiochirurgicznego leczenia wrodzonych wad serca, jest brak „idealnego" materiału wszczepialnego, niezbędnego do odbudowy uszkodzonych narządów.
Wykorzystanie maksymalnie biozgodnych lub wręcz żywych materiałów, takich jak hodowle tkankowe z komórek macierzystych, zbliża nowoczesną technologię medyczną do optymalnej odbudowy tkanek i narządów z materiału o garniturze genetycznym człowieka, a najlepiej własnym genomie każdego pacjenta [18].

\section{Edukacja}

W związku ze stopniem skomplikowania wrodzonych wad serca oczywistym wydaje się, że seria wydruków 3D danej wady serca u poszczególnych dzieci może pomóc w dokładniejszym przedstawieniu spektrum konfiguracji anatomicznych tej samej wady u różnych pacjentów. W związku z powyższym technika ta może stanowić istotny element dydaktyczny dla studentów i szkolących się lekarzy, wspomóc zrozumienie konkretnej wady serca oraz wskazać na różnorodność i szczegóły anatomiczne choroby. Bez dostępnego modelowania i projekcji symulującej sytuację obserwowaną „na żywo" szkolenie na tak zaawansowanym poziomie było trudne do przeprowadzenia, mimo wspomagania innymi sposobami wykorzystywanymi dotychczas w edukacji [3].

Dodatkowe, nowoczesne obrazowanie może się także stać pomocne we właściwej klasyfikacji i wciąż udoskonalanej nomenklaturze różnorodnych wad serca i naczyń oraz ich wariantów anatomicznych [19].

\section{Relacje z rodzicami chorych dzieci}

Należy podkreślić, że wydruki serca w technice 3D umożliwiają lekarzom prowadzącym leczenie dzieci z wrodzonymi wadami serca dokładne omówienie szczegółów danej wady z rodzicami dziecka. Model 3D pomaga również w sposób obrazowy wyjaśnić dostępne opcje terapeutyczne. Przyczynia się to z pewnością do pełniejszego zrozumienia aspektów wrodzonej wady serca u dziecka i pomaga w dyskusji lekarza z rodzicami na temat planowanego leczenia, potencjalnych możliwości terapii oraz związanych z nią zagrożeń. Poprzez takie działanie można także uzyskać lepsze relacje z rodzicami i ułatwić im decyzję o świadomej zgodzie na wykonanie procedury kardiochirurgicznej u ich dziecka.

\section{Materiały wszczepialne i narzędzia indywidualnie dostosowane do pacjenta}

Modele 3D umożliwiają również projektowanie i produkcję dostosowanych dla określonego pacjenta narzędzi umożliwiających przeprowadzenie planowanego zabiegu oraz implantacje przygotowanych elementów wszczepialnych. Należy tu wspomnieć o stentach wydrukowanych w technologii 3D, stosowanych na przykład w urologii [20]. Projektowanie z wykorzystaniem technik 3D pozwala na dokładne przygotowanie implantu do wydrukowania, zapewniając precyzyjne dopasowanie anatomiczne i skrócenie czasu 
operacji bez konieczności bezpośredniego „docinania”, wyginania i wpasowywania implantu, co opisywano w przypadku wydruków tytanowych uzupełnień żeber [21]. Co więcej, podkreśla się, że techniki wydruku 3D umożliwiają nieograniczone kształtowanie implantów dostosowanych dla danego chorego, włączając $w$ to rzadkie uwarunkowania kliniczne [12].

Przełomowe dla chirurgii klatki piersiowej wydaje się zastosowanie wydruku 3D do produkcji wszczepialnej zewnątrzoskrzelowo szyny podtrzymującej drożność oskrzela w tracheobronchomalacji. Technikę tę opisali po raz pierwszy w 2013 roku lekarze z amerykańskiego Uniwersytetu w Michigan. Implantacja zindywidualizowanego wydruku 3D w opisywanym wskazaniu i skuteczność tej metody leczenia sprawiła, że trwają prace rejestracyjne w celu akceptacji metody przez agencje rządowe (FDA, Food and Drug Administration) [5, 22].

\section{Wydruki 3D z materiału biologicznego - bioprinting}

Duży potencjał rozwoju technologii wydruków 3D wiąże się z zastosowaniem materiałów biologicznych, czyli tak zwane biowydruki (bioprinting). W technologii tej łączy się techniki inżynierii tkankowej z wydrukami 3D [22]. Obecnie kardiochirurgiczne zastosowanie technologii biowydruków 3D daje nadzieje na stworzenie wszczepialnej, dopasowanej do pacjenta zastawki aortalnej [9].

Oczekuje się, że technologia ta może także w niedługim czasie zrewolucjonizować leczenie wrodzonych wad serca u dzieci [8]. Obecnie w powszechnym zastosowaniu klinicznym brakuje materiału, który po wszczepieniu do organizmu dziecka wykazałby pełną biozgodność i oczekiwany wzrost wraz z rozwojem dziecka. Jest to niezwykle istotne zwłaszcza w wadach zastawkowych, których korekcja wymaga niekiedy uzupełnienia płatków zastawek, wszczepienia protezy uzupełniającej okolice okołozastawkową (droga wypływu komory serca) lub całkowitej wymiany. Technologię biowydruków 3D, która umożliwi wydrukowanie materiału o pełnej biozgodności, a następnie zapewni uzyskanie wybranego elementu przygotowanego dla określonego dziecka, będzie można uznać za krok milowy w kardiochirurgii dziecięcej.

Podsumowując, należy stwierdzić, że technika wydruków 3D w kardiochirurgii dziecięcej może istotnie poszerzyć możliwości terapeutyczne. Obecnie pomaga ona chirurgowi w orientacji przestrzennej u konkretnego dziecka, z uwzględnieniem szczegółów anatomicznych wady serca, oraz umożliwia planowanie przedoperacyjne zarówno w aspekcie strategii operacyjnej i możliwości technicznych, jak i zaplanowania odpowiedniego dostępu chirurgicznego. Działania te mogą w istotny sposób wpłynąć na bezpieczeństwo wykonywanych procedur medycznych, szczególnie interwencji kardiochirurgicznych i kardiologicznych w najbardziej skomplikowanych postaciach wrodzonych wad strukturalnych serca i naczyń.

Ograniczeniem zastosowania techniki wydruków 3D w kardiochirurgii dziecięcej jest niewątpliwie wgląd wyłącznie w statyczny model serca i wielkich naczyń bez uwzględnienia ich dynamiki (kurczliwość serca i naczyń), co może utrudniać pełne zrozumienie hemodynamicznych zmian w funkcjonowaniu układu krążenia dziecka. W celu uzyskania dobrej jakości wydruku 3D należy mieć dostęp do badań obrazowych (CT, rezonansu magnetycznego, cewnikowania serca z zastosowaniem odpowiednich technik wizualizacji). Dodatkowo należy podkreślić, że technologia ta - choć może być narzędziem niezwykle pomocnym - wiąże się z zaangażowaniem dodatkowego czasu i kosztów, co na obecnym etapie może ograniczyć wskazania do wykonania wydruków 3D do określonej, wybranej grupy pacjentów [2].

\section{Wnioski}

Druk 3D może być nieocenioną pomocą w planowaniu i leczeniu wrodzonych wad serca u dzieci. Stale ewoluująca technologia wydruków 3D umożliwi poprawę dokładności wydruków i stanie się użytecznym elementem w planowaniu leczenia dzieci z wrodzonymi wadami serca. Za pomocą technik biowydruków 3D może się okazać możliwe uzyskanie biozgodnych tkanek i elementów implantowalnych. Należy mieć nadzieję, że rozwój tej technologii rozwiąże w niedługim czasie nurtujące kardiochirurgów dziecięcych problemy związane z koniecznością uzupełniania tkanek dziecka materiałami sztucznymi lub kseno-/homograftami, które nie rosną wraz z dzieckiem.

\section{Konflikt interesów}

Autorzy nie zgłaszają jakiegokolwiek konfliktu interesów.

\section{Źródła finansowania}

Brak.

\section{Abstract}

$3 \mathrm{D}$ printing is more and more often applicated in modern medicine. We summarized present state of art regarding 3D printing technology and its capability in therapy of complex congenital heart diseases.

Key words: 3D printing, bioprinting, congenital heart disease, pediatric cardiac surgery

Folia Cardiologica 2016; 11, 5: 409-414 


\section{Piśmiennictwo}

1. Dodziuk H. Applications of $3 D$ printing in healthcare. Kardiochir. Torakochir. Pol. 2016; 13: 283-293.

2. Kim S. Three-dimensional printing: the next big thing in surgery? J. Thorac. Cardiovasc. Surg. 2016; 152: e9.

3. Powers M.K., Lee B.R., Silberstein J. Three-dimensional printing of surgical anatomy. Curr. Opin. Urol. 2016; 26: 283-288.

4. Park E.K., Lim J.Y., Yun I.S. i wsp. cranioplasty enhanced by three-dimensional printing: custom-made three-dimensional-printed titaniumimplants for skull defects. J. Craniofac. Surg. 2016; 27: 943-994.

5. Zopf D.A., Hollister S.J., Nelson M.E. i wsp. Bioresorbable airway splint created with a three-dimensional printer. N. Engl. J. Med. 2013; 368: 2043-2045.

6. Hermsen J.L., Burke T.M., Seslar S.P. i wsp. Scan, plan, print, practice, perform: Development and use of a patient-specific 3-dimensional printed model in adult cardiac surgery. J. Thorac. Cardiovasc. Surg. 2016; 20; pii: S0022-5223(16)30937-0.

7. Lueders C., Jastram B., Hetzer R., Schwandt H. Rapid manufacturing techniques for the tissue engineering of human heart valves. Eur. J. Cardiothorac. Surg. 2014; 46: 593-601.

8. Li J., Chen M., Fan X., Zhou H. Recent advances in bioprinting techniques: approaches, applications and future prospects. J. Transl. Med. 2016; 14: 271.

9. Jana S., Lerman A. Bioprinting a cardiac valve. Biotechnol. Adv. 2015; 33: 1503-1521.

10. Duan B., Hockaday L.A., Kang K.H., Butcher J.T. 3D bioprinting of heterogeneous aortic valve conduits with alginate/gelatin hydrogels. J. Biomed. Mater. Res. A 2013; 101: 1255-1264.

11. Duan B., Kapetanovic E., Hockaday L.A., Butcher J.T. Three-dimensional printed trileaflet valve conduits using biological hydrogels and human valve interstitial cells. Acta Biomater. 2014; 10: 1836-1846.

12. Kurenov S.N., Ionita C., Sammons D., Demmy T.L. Three-dimensiona printing to facilitate anatomic study, device development, simulation, and planning in thoracic surgery. J. Thorac. Cardiovasc. Surg. 2015; 149: 973-979.e1.
13. Jaworski R., Haponiuk I., Chojnicki M. i wsp. 3D printing technology helps surgery planning in patients with congenital heart disease. Kardiol. Pol. 2016; 74 [praca przyjęta do druku 20.09.2016].

14. Noecker A.M., Chen J.F., Zhou Q. i wsp. Development of patient-specific three-dimensional pediatric cardiac models. ASAIO J. 2006; 5 : 349-353.

15. Hui D.S., Lee R. Scan, plan, print, practice, perform: a disruptive technology? J. Thorac. Cardiovasc. Surg. 2016 Sep 17. pii: S00225223(16)31131-X.

16. Yang D.H., Kang J.W., Kim N. i wsp. Myocardial 3-dimensional printing for septal myectomy guidance in a patient with obstructive hypertrophic cardiomyopathy. Circulation 2015; 132: 300-301.

17. Schmauss D., Juchem G., Weber S. i wsp. Three-dimensional printing for perioperative planning of complex aortic arch surgery. Ann. Thorac. Surg. 2014; 97: 2160-2163.

18. Nożyński J.K., Grzybek H., Zembala-Nożyńska E. i wsp. Cellular viability and ultrastructure of stented, antibiotic sterilized and cryopreserved sheep biological valves implanted for one year in tricuspid position. Ann. Transpl. 2003; 8: 70-78.

19. Jacobs J.P., Jacobs M.L., Maruszewski B. i wsp. Initial application in the EACTS and STS Congenital Heart Surgery Databases of an empirically derived methodology of complexity adjustment to evaluate surgical case mix and results. Eur. J. Cardiothorac. Surg. 2012; 42: 775-779.

20. Del Junco M., Yoon R., Okhunov Z. i wsp. Comparison of flow characteristics of novel three-dimensional printed ureteral stents versus standard ureteral stents in a porcine model. J. Endourol. 2015; 29: 1065-1069.

21. Wang L., Cao T., Li X., Huang L. Three-dimensional printing titanium ribs for complex reconstruction after extensive posterolateral chest wall resection in lung cancer. J. Thorac. Cardiovasc. Surg. 2016; 152: e5-e7.

22. Kaye R., Goldstein T., Zeltsman D. i wsp. Three dimensional printing: a review on the utility within medicine and otolaryngology. Int. J. Pediatr. Otorhinolaryngol. 2016; 89: 145-148. 